\title{
The Effect of SARS Outbreak on Corporate Investments
}

\author{
Submitted 17/03/21, $1^{\text {st }}$ revision 11/04/21, $2^{\text {nd }}$ revision 30/04/21, accepted $25 / 05 / 21$
}

$$
\text { Mona Yaghoubi }{ }^{1} \text {, Reza Yaghoubi }{ }^{2}
$$

\begin{abstract}
:
Purpose: This study examines the impact of pandemics on corporate investments using the severe acute respiratory syndrome (SARS) outbreak as the variable of interest and firm-level capital expenditures, acquisition expenses, and research and development expenditures as proxies for corporate investments.

Methodology/Design/Approach: Our sample consists of firms listed in the Shenzhen, Shanghai, Hong Kong, and Toronto stock exchanges from 1999 to 2019.

Findings: We find that the SARS outbreak had no significant impact on the capital expenditure, acquisitions, or research and development expenses of the firms listed in Canada. SARS also had no significant effect on the Chinees firms' capital expenditure and acquisitions expenses but increased their research and development expenses.

Practical Implications: Understanding this relationship helps firms to modify their corporate investment strategies.

Originality/Value: Investigating this relationship is important because of the significant risk's pandemics impose upon firms and the global economy. This study adds to the stream of research investigating the impact of exogenous shocks on corporate investments.
\end{abstract}

Keywords: Pandemics, corporate investment, capital expenditure, acquisitions, research, and development.

JEL Classification: G31.

Research type: Research paper.

${ }^{I}$ The University of Canterbury, School of Economics and Finance, mona.yaghoubi@canterbury.ac.nz;

${ }^{2}$ Waikato Institute of Technology, Centre for Business and Enterprise, reza.yaghoubi@wintec.ac.nz; 


\section{Introduction}

Pandemics are exogenous shocks with severe economic impacts on countries and businesses that can last for years. We live in a world where viruses do not have geographic borders and are only one flight away from one country to another. Therefore, the exogenous shock from pandemics can have a global impact and is thus essential to study. In frictionless capital markets, while idiosyncratic risk can be eliminated through diversification, only systematic risk is relevant in making investment decisions. For corporations to maximize shareholders' wealth, they need to invest in positive net present value (NPV) projects. An increase in systematic risk increases the cost of capital necessary to fund investment opportunities, which negatively affects the added value from such investments.

The empirical literature does not explore the effect of exogenous shocks due to pandemics on corporate investments. This study employs the severe acute respiratory syndrome (SARS) outbreak in 2003 and listed firms in the Shenzhen, Shanghai, Hong Kong, and Toronto stock exchanges to document new evidence on the impact of pandemics on corporate investments. This is important because of the significant risks that pandemics impose upon firms and the global economy. This study adds to the stream of research that investigates the impact of exogenous shocks on corporate investments.

\section{Literature Review}

The NPV of an investment indicates the added value of the investment project to a firm. Mathematically, the NPV of a future project is affected by the firm's cost of capital and the projected cash flows from the potential investment. The higher the opportunity cost of capital and the lower the projected cash flows, the lower the added value to the firm from its investment opportunity. Therefore, if the exogenous shocks due to a pandemic affect the opportunity cost of capital and the projected cash flows, the value of an investment opportunity decreases.

$N P V=-$ Initial investment $+\frac{C F_{1}}{(1+r)^{1}}+\frac{C F_{2}}{(1+r)^{2}}+\cdots+\frac{C F_{n}}{(1+r)^{n}}$,

where NPV is the net present value, $r$ is the opportunity cost of capital and $C F$ is the projected cash flows in each year.

Using the Black and Scholes (1973) option pricing model, Merton (1974) develops a model to price the debt and equity. Merton (1974) shows the value of levered firm equity is equal to the value of a European call option, and the value of the firm debt is the value of the risk-free debt minus the value of a European put option. The Black and Scholes (1973) model indicates that the higher the volatility, the higher the value of European put and call options. Therefore, when volatility increases, the value of a firm's debt decreases. Decreases in debt value increase the cost of debt. Exogenous shocks like the SARS outbreak increase the volatility of a firm's stock return and its 
cost of debt. Also, the existing literature suggests that shocks, such as natural disasters and recessions, lead to bank credit tightening (Duchin, Ozbas, and Sensoy, 2010). Despite monetary easing policies put in place by central banks, credit tightening impairs firms' access to capital and increases financing costs (Shleifer and Vishny, 2010; Gorton, 2010).

On the other hand, a decrease in firms' value reduces their borrowing power by reducing the collateral that they can borrow against (Brunnermeier and Oehmke, 2013). Moreover, projected operating cash flows decline in light of the pandemic due to the decline in consumer credit and spending. This combination of higher financing costs and lower projected cash flows means a lower valuation for potential capital investments. Since fewer potential capital investments can pass the minimum return threshold, total capital investment declines, reducing the demand for financing (Kahle and Stulz, 2013; Grima et al., 2020; Khan et al., 2020).

Once the pandemic is controlled and the crisis ends, corporate investments are expected to bounce back. Therefore, we hypothesize that global pandemics harm corporate capital investments in the short term, but these investments will rebound in the post-pandemic period.

SARS was first identified in Southern China and soon spread to more than 26 countries in early 2003. According to the World Health Organization (WHO), SARS is a viral respiratory disease caused by a SARS-associated coronavirus, and $20 \%$ of adults and $50 \%$ of children infected with SARS develop respiratory failure (Wong and Leung, 2007). Besides its health and social impacts, SARS had severe economic impacts on the countries affected by it. For example, in the second quarter of 2003, household income in Shaanxi Province in China decreased by $22.36 \%$, and the global macroeconomic impact of SARS was around 30-100 billion dollars (Qiu et al., 2018).

To find the effect of pandemics on corporate investments, we follow the literature and use firms' capital expenditure and acquisition expenses as proxies for corporate investments (Eisfeldt and Rampini, 2006; DeAngelo et al., 2011; Grima et al., 2020; Khan et al., 2020). We also use research and development expenses as a proxy for firms' investment. The variable of interest is a dummy variable indicating the SARS outbreak year, and we conjecture that the coefficient associated with our variable of interest is negative in the SARS year and positive in the year after the outbreak.

Our sample consists of firms listed in the Shenzhen, Shanghai, Hong Kong, and Toronto stock exchanges. We obtain annual firm-level data from the ThomsonReuters DataStream Database from 1999 to 2019. We choose firms listed in these exchanges, as China and Canada were significantly affected by the SARS outbreak. We test the data of the two Mainland China exchanges, the Hong Kong exchange and the Toronto exchange, separately, as there are differences in ownership and governance structures in different countries.

To test our hypotheses, we employ a panel ordinary least squares model with a firm 
fixed effect and follow the literature and control for firm-specific characteristics such as size, turnover, market-to-book ratio, debt ratio, and cash ratio (Alstadsæter, Jacob, and Michaely, 2017). Our findings suggest that the SARS outbreak had an immediate negative impact on corporate investments, using Canadian and Hong Kong data. Furthermore, our results indicate that corporate investment measured by capital expenditures rebounded the following year significantly. Moreover, we find no statistically significant changes in research and development spending due to pandemics. This observation holds even when we examine a sub-sample of pharmaceutical and biotech firms.

\section{Empirical Analysis}

We use a sample of publicly listed firms in China and Canada - the two countries severely affected by SARS - to test our hypothesis that the SARS outbreak impacted corporate investments. Our sample consists of firms listed in the Shenzhen, Shanghai, Hong Kong, and Toronto stock exchanges from 1999 to 2019. We perform a crosscountry (stock exchange) analysis, as the impact of the SARS outbreak pandemic was different in different countries.

At the same time, different countries have different corporate governance structures and macro-level factors that can affect corporate investment differently. Since firms' policies may differ by investment types, we test the corporate investment proxies separately. The proxies for our key dependent variable are capital expenditure, acquisition expenses, and research and development expenditures. Our variable of interest (SARS) is a dummy variable equal to 1 in 2003 and zero otherwise.

Following the literature, we control for firm-level variables that may affect corporate investments. These variables include debt ratio, cash ratio, size, turnover ratio, investment in the previous year, and market-to-book ratio as a proxy for a firm's growth opportunities. We also control for pre-pandemic macroeconomic shocks using World Bank per capita GDP data. We estimate the regression model below:

$\ln$ Investment $_{i t}=\beta_{0}+\beta_{1}$ SARS $+\beta_{2} \ln$ Investment $_{i t-1}+\beta_{3} \ln G D P_{t}+$ $\beta_{4} X_{i, t-1}++\beta_{3} \lambda_{i}+\varepsilon_{i t}$,

where $\ln$ Investment $_{i t}$ is the natural logarithm of acquisitions (Acq), capital expenditures $(C a p X)$ and research and development expenses $(R n D)$ of firm $i$ across pandemic and post-pandemic years.

$X_{i, t-1}$ is a matrix of lagged firm-level control variables listed in the Appendix, $S A R S_{t}$ is a dummy variable equal to one in a pandemic year and zero otherwise, $\lambda_{i}$ is the firm-specific fixed effect and $\varepsilon_{i t}$ is the error term. The standard errors are clustered by firm.

We repeat our estimations for the two years following the outbreak to examine the 
longer-term impact of the SARS outbreak on investments.

Tables 1 and 2 show the summary statistics and the correlation coefficients between the variables of this study. Panel A of Tables 1 and 2 reports using listed firms on the Shenzhen, Shanghai, and Hong Kong stock exchanges, and Panel B of Tables 1 and 2 reports using the listed firms on the Toronto stock exchange. Table 1 indicates that, on average, Canadian firms spend more on their research and development, capital expenditure, and acquisitions. The table also shows that, on average, firms listed in both countries have a similar book-to-debt ratio at around 0.43 . Also, listed firms in China have more growth opportunities and hold less cash than firms listed in the Toronto stock exchange.

Table 1. Descriptive statistics of the key variables used in this study.

Panel A: China

\begin{tabular}{|lrrrrrrrr|}
\hline Stats & $\mathrm{N}$ & mean & $\mathrm{p} 25$ & $\mathrm{p} 50$ & $\mathrm{p} 75$ & $\max$ & $\mathrm{min}$ & \multicolumn{2}{c|}{ sd } \\
RnD & 34530 & 1.239 & 0.000 & 0.0249 & 1.929 & 70.36 & 0.000 & 2.243 \\
Capx & 34530 & 0.055 & 0.015 & 0.039 & 0.078 & 4.408 & -0.274 & 0.060 \\
Acq & 34529 & 0.005 & 0.000 & 0.000 & 0.000 & 0.944 & -0.659 & 0.025 \\
SARS & 34546 & 0.027 & 0.000 & 0.000 & 0.000 & 1.000 & 0.000 & 0.162 \\
BDR & 34524 & 0.439 & 0.268 & 0.428 & 0.590 & 3.248 & 0.015 & 0.226 \\
Cash & 34546 & 0.061 & 0.000 & 0.000 & 0.089 & 0.788 & 0.000 & 0.111 \\
Size & 34530 & 12.79 & 11.72 & 12.61 & 13.63 & 18.27 & 7.543 & 1.592 \\
MtB & 28113 & 0.210 & 0.084 & 0.155 & 0.270 & 1.969 & 0.005 & 0.193 \\
Turnover & 31605 & 0.796 & 0.380 & 0.637 & 0.996 & 4.056 & 0.043 & 0.657 \\
\hline
\end{tabular}

Panel B: Panel C: Canada

\begin{tabular}{|lcccccccc|}
\hline stats & $\mathrm{N}$ & $\mathrm{m}$ ean & $\mathrm{p} 25$ & $\mathrm{p} 50$ & $\mathrm{p} 75$ & $\mathrm{max}$ & \multicolumn{1}{l}{ min } & sd \\
RnD & 17921 & 2.291 & 0.000 & 0.000 & 0.000 & 273.7 & -51.08 & 10.15 \\
Capx & 17921 & 7.779 & 0.926 & 4.047 & 10.37 & 299.6 & -2.788 & 10.89 \\
Acq & 17921 & 1.528 & 0.000 & 0.000 & 0.000 & 75.21 & -85.98 & 5.675 \\
SARS & 18465 & 0.054 & 0.000 & 0.000 & 0.000 & 1.000 & 0.000 & 0.225 \\
BDR & 17777 & 0.434 & 0.181 & 0.407 & 0.605 & 2.147 & 0.003 & 0.338 \\
Cash & 11645 & 0.116 & 0.009 & 0.041 & 0.131 & 0.916 & 0.000 & 0.184 \\
Size & 17921 & 11.96 & 10.45 & 11.92 & 13.47 & 17.56 & 5.598 & 2.329 \\
MtB & 16716 & 0.143 & 0.043 & 0.080 & 0.149 & 1.517 & 0.004 & 0.214 \\
Turnover & 5930 & 0.791 & 0.099 & 0.494 & 1.110 & 5.057 & 0.000 & 0.946 \\
\hline
\end{tabular}

Source: Author's own creation.

Table 2. Correlations between the variables of the study.

Panel A: China

\begin{tabular}{|c|c|c|c|c|c|c|c|c|c|}
\hline & (1) & (2) & (3) & (4) & (5) & (6) & (7) & (8) & (9) \\
\hline (1) $R n D$ & 1 & & & & & & & & \\
\hline (2) Capx & -0.011 & 1 & & & & & & & \\
\hline (3) $A c q$ & 0.062 & -0.033 & 1 & & & & & & \\
\hline (4) $S A R S$ & -0.090 & 0.021 & -0.028 & 1 & & & & & \\
\hline (5) $B D R$ & -0.223 & -0.104 & -0.048 & 0.029 & 1 & & & & \\
\hline (6) Cash & 0.136 & -0.068 & 0.026 & -0.007 & -0.105 & 1 & & & \\
\hline
\end{tabular}




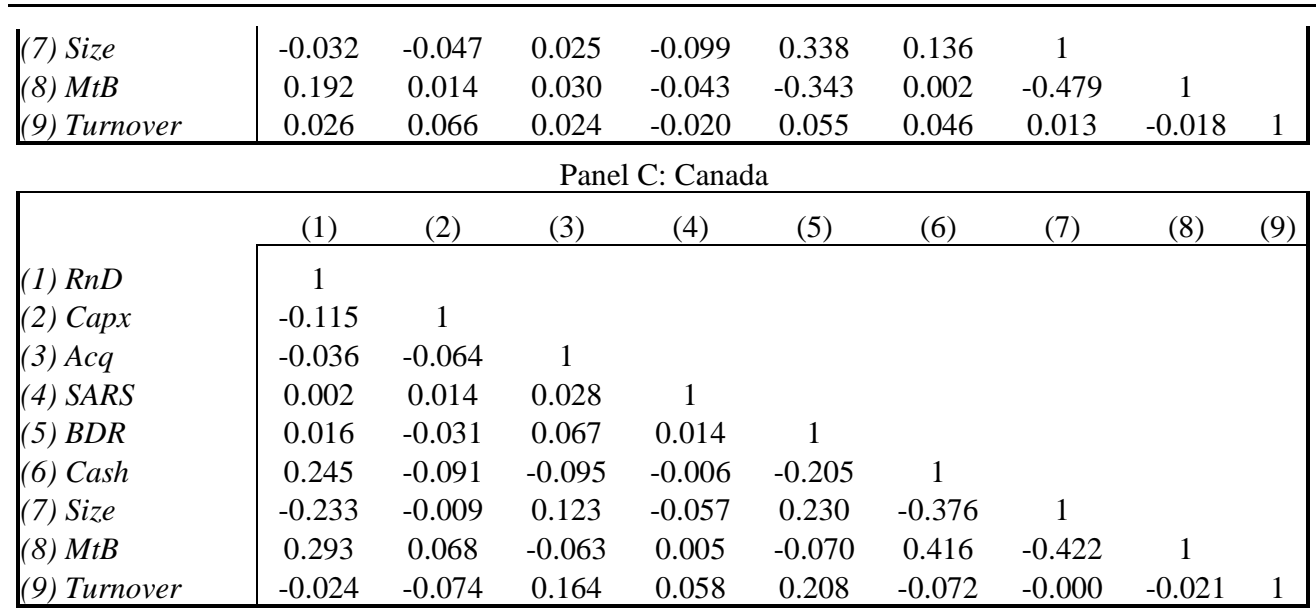

Source: Author's own creation.

Panels A and B of Table 3 present the estimation results of Equation (1) using a sample of Chinese and Canadian listed firms, respectively. Columns (1) through (9) of the table document the relationship between the SARS outbreak and corporate investment measured by the natural logarithm of research and development expenses (RnD), capital expenditure (Capx), and acquisitions (Acq). The table reports results for the first year of the SARS outbreak and the two post-pandemic years.

According to the results presented in Table 1, there is no statistically significant relationship between our variable of interest (SARS) and capital expenditure (Capx) and acquisition variables (Acq), indicating that the SARS outbreak affects corporate investments in neither China nor Canada. However, Panel A of Table 1 shows a positive and statistically significant relationship between the $\mathrm{RnD}$ measure of investment and the SARS outbreak, indicating that during the SARS outbreak year and one year after that, Chinese firms spent more on their research and development.

We also ran several robustness checks. First, following Kothari, Lewellen, and Warner (2014), we added the net income and stock return of the year before the pandemic outbreak, and the result remained unchanged. Second, we checked the pharma and biotech companies separately, and the result did not change. Third, we checked the sample excluding pharma and biotech firms, and the results remain unchanged. Fourth, we checked for industry fixed effect instead of firm fixed effect, and the result did not change.

Table 3. Summary of the results of Testing Equation (1).

\begin{tabular}{|c|c|c|c|c|c|c|c|c|c|}
\hline VARIABLES & $\begin{array}{c}(1) \\
R n D_{t}\end{array}$ & $\begin{array}{c}(2) \\
R n D_{t+1}\end{array}$ & $\begin{array}{c}(3) \\
R n D_{t+2} \\
\end{array}$ & $\begin{array}{c}(4) \\
\text { Capx }_{t} \\
\end{array}$ & $\begin{array}{c}(5) \\
\operatorname{Capx}_{t+1} \\
\end{array}$ & $\begin{array}{c}(6) \\
\text { Capx }_{t+2} \\
\end{array}$ & $\begin{array}{c}(7) \\
\text { Acq } \\
\end{array}$ & $\begin{array}{c}(8) \\
\text { Acq } \\
\text { t+1 }\end{array}$ & $\begin{array}{c}(9) \\
\text { Acq }{ }_{t+2} \\
\end{array}$ \\
\hline SARS & $\begin{array}{c}0.109^{* *} \\
*\end{array}$ & $0.066^{* * *}$ & 0.000 & -0.174 & -0.162 & -0.471 & -0.000 & 0.0798 & 0.094 \\
\hline$R n D$ & $\begin{array}{c}(0.021) \\
0.371^{* *}\end{array}$ & $\begin{array}{c}(0.021) \\
0.505^{* * *}\end{array}$ & $\begin{array}{c}(0.015) \\
0.504 * * *\end{array}$ & $(0.189)$ & $(0.167)$ & $(0.162)$ & $(0.058)$ & $(0.047)$ & $(0.074)$ \\
\hline
\end{tabular}




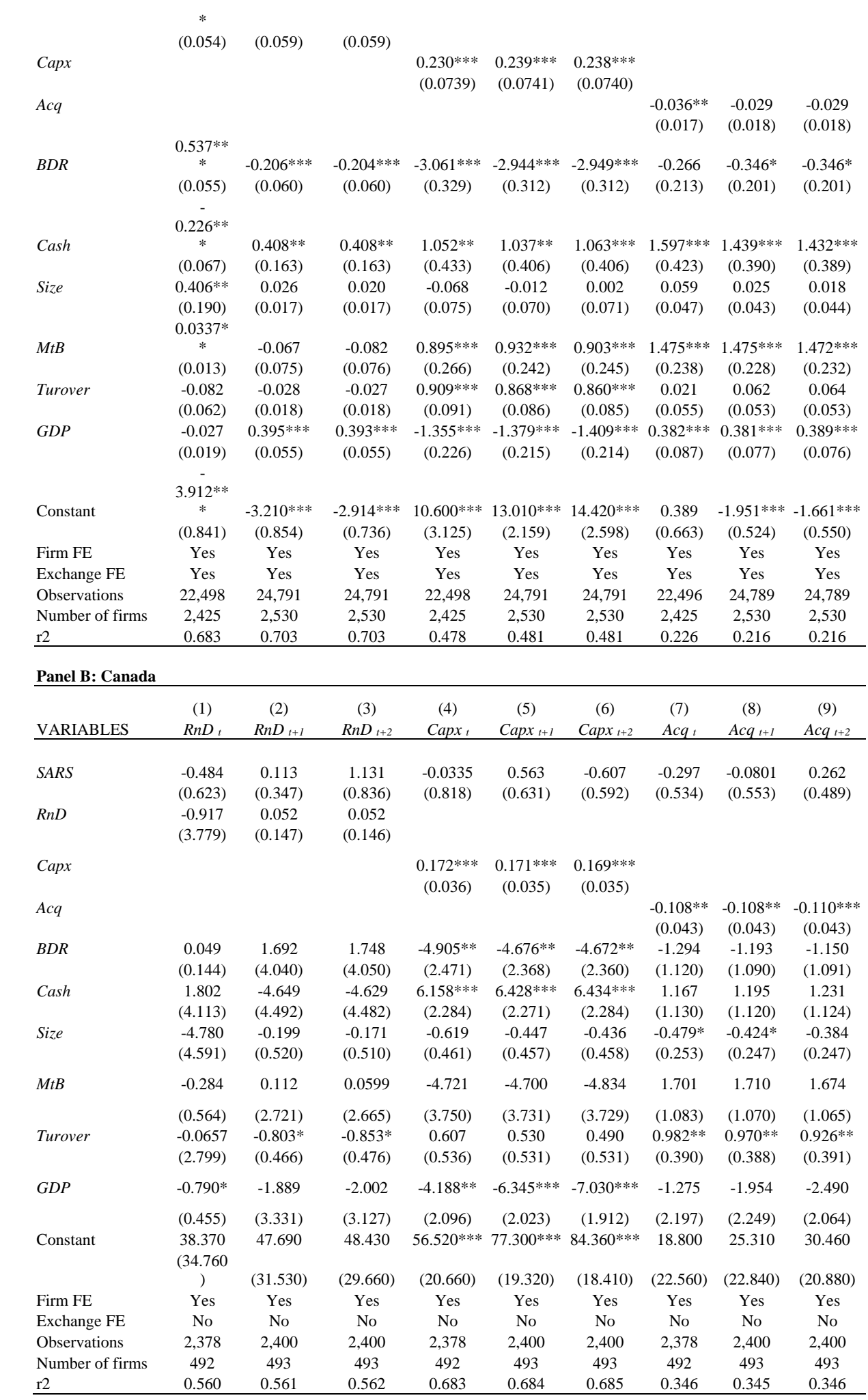


$* * * p<0.01 * * p<0.05, * p<0.1$

Note: Panel A uses a sample of listed firms in Shenzhen, Shanghai, Hong Kong Stock Exchanges and Panel B uses a sample of listed firm on Toronto stock exchanges from 1999 to 2019. To control for simultaneity all control variables are lagged.

Source: Author's own creation.

\section{Conclusion}

For the first time, we document the impact of the SARS outbreak on corporate investments in China and Canada using a large sample of 27,191 firm-years in those two countries. Our findings suggest that the SARS outbreak did not affect any part of the aggregate of corporate investments in China and Canada in the year of the outbreak or the subsequent two years. We find that the outbreak had no significant impact on the capital expenditure, acquisitions, or research and development expenses of the firms listed in Canada but increased the research and development expenses among Chinese firms. Our finding is consistent across industry clusters. We suggest further investigation into the COVID-19 pandemic once sufficient data are available.

\section{References:}

Alstadsæter, A., Jacob, M., Michaely, R. 2017. Do dividend taxes affect corporate investment? Journal of Public Economics, 151, 74-83.

Black, F., Scholes, M. 1973. The pricing of options and corporate liabilities. Journal of Political Economy, 81(3), 637-654.

Boudreaux, C.J., Escaleras, M.P., Skidmore, M. 2019. Natural disasters and entrepreneurship activity. Economics Letters, 182, 82-85.

Brunnermeier, M.K., Oehmke, M. 2013. Bubbles, financial crises, and systemic risk. In G. Constantinides, Handbook of the Economics of Finance, 2, 1221-1288. Amsterdam: Elsevier.

DeAngelo, H., DeAngelo, L., Whited, T.M. 2011. Capital structure dynamics and transitory debt. Journal of Financial Economics, 99(2), 235-261.

Duchin, R., Ozbas, O., Sensoy, B.A. 2010. Costly external finance, corporate investment, and the subprime mortgage credit crisis. Journal of Financial Economics, 97, 418-435.

Eisfeldt, A.L., Rampini, A.A. 2006. Capital reallocation and liquidity. Journal of monetary Economics, 53(3), 369-399.

Frank, M.Z., Goyal, V.K. 2009. Capital structure decisions: Which factors are reliably important? Financial management, 38(1), 1-37.

Gorton, G.B. 2010. Slapped by the invisible hand: The panic of 2007. USA: Oxford University Press.

Grima, S., Dalli Gonzi, R., Thalassinos, I.E. 2020. The Impact of COVID-19 on Malta and its Economy and Sustainable Strategies. Available at: SSRN: https://ssrn.com/abstract=3644833.

Kahle, K.M., Stulz, R.M. 2013. Access to capital, investment, and the financial crisis. Journal of Financial Economics, 2(110), 280-299.

Khan, S., Rabbani, R.M., Thalassinos, I.E., Atif, M. 2020. Corona Virus Pandemic Paving Ways to Next Generation of Learning and Teaching: Futuristic Cloud Based Educational Model. Available at SSRN: https://ssrn.com/abstract=3669832. 
Keefe, M.O.C., Yaghoubi, M. 2016. The influence of cash flow volatility on capital structure and the use of debt of different maturities. Journal of Corporate Finance, 38, 18-36.

Kothari, S.P., Lewellen, J., Warner, J.B. 2014. The behavior of aggregate corporate investment. Simon Graduate School of Business, University of Rochester.

Merton, R.C. 1974. On the pricing of corporate debt: The risk structure of interest rates. The Journal of Finance, 29(2), 449-470.

Qiu, W., Chu, C., Mao, A., Wu, J. 2018. The impacts on health, society, and economy of SARS and H7N9 outbreaks in China: A case comparison study. Journal of Environmental and Public Health.

Shleifer, A., Vishny, R.W. 2010. Unstable banking. Journal of Financial Economics, 3(97), 306-318.

Welch, I. 2011. Two common problems in capital structure research: The financial-debt-toasset ratio and issuing activity versus leverage changes. International Review of Finance, 11(1), 1-17.

Wong, G.W., Leung, T.F. 2007. Bird flu: Lessons from SARS. Paediatric Respiratory Reviews, 8(2), 171-176.

\section{Appendix:}

Table A1. Variable definitions

\begin{tabular}{|c|c|c|}
\hline Variables & Definition & Data Source \\
\hline BDR & The ratio of total liabilities over total assets (Welch, 2011) & Datastream \\
\hline Cash & $\begin{array}{l}\text { The ratio of cash and marketable securities over total assets } \\
\text { (DeAngelo, DeAngelo, and Whited, 2011) }\end{array}$ & Datastream \\
\hline $\begin{array}{l}\text { GDP }(\log ) \\
\text { PPP }\end{array}$ & $\begin{array}{l}\text { The logged value of real GDP, adjusted for purchasing power parity } \\
\text { (PPP) (Boudreaux, Escaleras, and Skidmore, 2019) }\end{array}$ & World Bank \\
\hline Size & $\begin{array}{l}\text { The natural logarithm of total firm assets (Keefe and Yaghoubi, } \\
\text { 2016) }\end{array}$ & Datastream \\
\hline $\begin{array}{l}\text { Market to } \\
\text { Book }\end{array}$ & $\begin{array}{l}\text { The ratio of a firm's market value of assets to total assets (Keefe and } \\
\text { Yaghoubi, 2016) }\end{array}$ & Datastream \\
\hline $\operatorname{RnD}(\log )$ & $\begin{array}{l}\text { Natural logarithm of one plus a firm's research and development } \\
\text { expenses (Frank and Goyal, 2009). }\end{array}$ & Datastream* \\
\hline Turnover & $\begin{array}{l}\text { The ratio of sales to the previous year's total assets (Alstadsæter, } \\
\text { Jacob and Michaely, 2017) }\end{array}$ & Datastream \\
\hline CapX $(\log )$ & $\begin{array}{l}\text { The natural logarithm of one plus the ratio of capital expenditure } \\
\text { over total assets }\end{array}$ & Datastream \\
\hline Acq $(\log )$ & $\begin{array}{l}\text { The natural logarithm of one plus the ratio of acquisitions spending } \\
\text { over total assets }\end{array}$ & Datastream \\
\hline MtB & $\begin{array}{l}\text { The ratio of the market value of assets by the book value of assets } \\
\text { (Keefe and Yaghoubi, 2016) }\end{array}$ & Datastream \\
\hline SARS & A dummy variable $=1$ if a year is 2003 , and zero otherwise & WHO \\
\hline
\end{tabular}

Note: This table presents the definitions of the variables used by this study.

*Research and development expenses represent all direct and indirect costs related to the creation and development of new processes, techniques, applications and products with commercial possibilities. Contributions by government, customers, partnerships or other corporations to the company's research and development expense

Source: Author's own creation. 
